\title{
Are salmon-derived nutrients being incorporated in food webs of invaded streams? Evidence from southern Chile
}

\author{
I. Arismendi( ${ }^{(1) \star}$, and D. Soto ${ }^{(2)}$
}

Received January 4, 2012

Revised March 6, 2012

Accepted March 6, 2012

\section{ABSTRACT}

Key-words: invasive species, Patagonia, salmonids, periphyton, freshwater snail

Using stable isotope analyses of $\mathrm{N}$ and $\mathrm{C}$ we present preliminary evidence of marine-derived nutrients from introduced Chinook salmon (Oncorhynchus tshawytscha Walbaum) in stream food webs of Laguna Los Patos, NW Patagonia. Similar to values reported within Chinook salmon's native distributional range periphyton and aquatic insects are the trophic levels that show the greatest enrichment of $\delta^{15} \mathrm{~N}(5-6 \%)$. Since there is a rapid expansion of Chinook salmon in South America future effort is needed to elucidate the mechanisms and consequences of nutrients subsidies from salmon carcasses in those invaded ecosystems.

\section{RÉSUMÉ}

Les nutriments dérivés du saumon sont-ils incorporés dans les réseaux trophiques des cours d'eau envahis ? Un cas au sud du Chili.

Mots-clés: $\quad$ En utilisant l'analyse des isotopes stables de $\mathrm{N}$ et $\mathrm{C}$, nous présentons des espèces envahissantes, Patagonie, salmonidés, périphyton, mollusques d'eau douce données préliminaires indiquant que les éléments nutritifs provenant du saumon Chinook introduit (Oncorhynchus tshawytscha Walbaum) entrent dans le réseau trophique de la rivière Laguna Los Patos, NW Patagonie. Comme pour les valeurs rapportées dans l'aire de répartition d'origine du saumon Chinook, le périphyton et les insectes aquatiques sont les niveaux trophiques qui montrent le plus grand enrichissement de $\delta^{15} \mathrm{~N}(5-6 \%$ \%). Comme il s'agit d'une expansion rapide du saumon Chinook en Amérique du Sud, un effort de recherche est nécessaire pour comprendre les mécanismes et les conséquences des apports en substances nutritives provenant des carcasses de saumons dans ces écosystèmes envahis.

Marine derived nutrients (MDN) from Chinook salmon carcasses play an important role by providing nutrients to freshwater ecosystems in the Northern Hemisphere (Wold et al., 1999; Wipfli et al., 2003; Claeson et al., 2006; Verspoor et al., 2011). The impact of MDN on stream food webs is often manifested through increased production of periphyton and biofilm (Wold et al., 1999; Kohler et al., 2008) and the subsequent productivity of higher trophic levels (Claeson et al., 2006; Kohler et al., 2008). MDN from salmon carcasses have been shown to

(1) College of Ocean, Earth, and Atmospheric Sciences, Oregon State University, 104 CEOAS Admin Bldg, Corvallis, 97331 Oregon, USA

(2) Inland Water Resources and Aquaculture Service (FIRI), Fisheries Department, FAO of United Nations, Via delle Terme di Caracalla, 00100, Rome, Italy

*Corresponding author: Ivan.Arismendi@oregonstate.edu. 


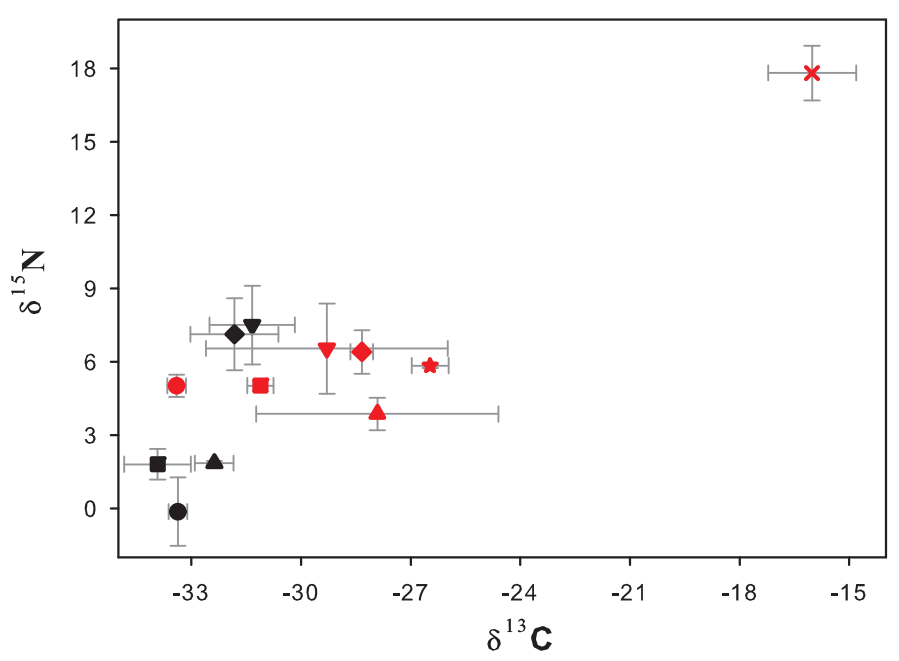

\section{Figure 1}

Dual stable isotopes plot of food webs in the stream influenced by MDN from salmon carcasses Laguna Los Patos (red symbols) and in the reference stream Rio Pescado (filled symbols). Symbols (mean \pm SE) represent peryphyton (circle), freshwater snail (triangle), aquatic insects (square), brown trout (diamond), rainbow trout (inverted triangle), Chinook salmon fry (star), and Chinook salmon carcasses ( $\times$ symbol).

increase the growth rate of resident salmonids in streams and improve the freshwater and marine salmon production (Wipfli et al., 2003).

In recent decades, rapid colonization and establishment of self-sustaining populations of Chinook salmon (Oncorhynchus tshawytscha Walbaum) have occurred in South America (Becker et al., 2007; Soto et al., 2007; Correa and Gross, 2008; Di Prinzio and Pascual, 2008) and New Zealand (McDowall, 1994). Although MDN from salmon carcasses provide multiple benefits in ecosystems where Chinook salmon is native, whether or not similar benefits will occur in systems in which they are introduced remains unclear. Additionally, it is also not known whether the nutrients from introduced salmon carcasses become incorporated into the aquatic food webs in the same way.

Several studies conducted in North America have used stable isotopes of carbon (C) and nitrogen $(\mathrm{N})$ to address the importance of MDN from salmon carcasses transported into freshwaters (e.g. Wold et al., 1999; Chaloner et al., 2002; Claeson et al., 2006; Kohler et al., 2008). During their ocean life history, adult Chinook salmon incorporate heavier isotopes of $C$ and $\mathrm{N}$ from marine sources and because they do not feed when they enter to the freshwater this signature is retained and different than a terrestrial or freshwater origin. Thus, food webs that incorporate MDN from salmon carcasses should show predictable changes from their previous natural isotopic signatures. Here, by using stable isotopes of $\mathrm{C}$ and $\mathrm{N}$ we examine if MDN from salmon carcasses are being incorporated in food webs of an invaded stream where Chinook salmon have become established in recent decades. Our results provide the first attempt to evaluate the importance of MDN from salmon carcasses in Patagonia which is essential information to testing impacts of Chinook salmon invasions in southern South America and elsewhere.

We sampled in two adjacent Andean streams within $20 \mathrm{~km}$, Laguna Los Patos (invaded by Chinook salmon) and Rio Pescado (not-invaded), both located in the Chilean Lakes Region in southern South America (39 $\left.30^{\circ}-43^{\circ} 35^{\prime} \mathrm{S}\right)$. We selected these two streams based on their high similarity of key characteristics that influence the stream productivity and thus, we minimize potential confounding factors that could obscure our results of MDN in their food webs (e.g., light, discharge, substrate, geology, biota; Figure 1 and Table I). Both sites originate on volcanic slopes of 2000-2700 m elevation and drain relatively pristine watersheds with riparian vegetation dominated by the Valdivian temperate rainforest. As part of the Vicente Perez Rosales National Park, Laguna Los Patos is the first and most studied 
Table I

Characteristics of the two selected streams (Laguna Los Patos and Rio Pescado) sampled in April-May of 2007-2008. Mean values were obtained during the sampling period.

\begin{tabular}{|c|c|c|}
\hline & $\begin{array}{l}\text { Laguna Los Patos } \\
\text { river with Chinook }\end{array}$ & $\begin{array}{l}\text { Rio Pescado } \\
\text { reference river without Chinook }\end{array}$ \\
\hline *UTM coordinate East & 713332 & 68571 \\
\hline *UTM coordinate North & 5438389 & 5429128 \\
\hline Watershed area (ha) & 7869 & 7729 \\
\hline Main watershed name & Petrohue & Maullin \\
\hline Mean stream flow $\left(\mathrm{m}^{3} \cdot \mathrm{s}^{-1}\right)$ & 5.4 & 4.9 \\
\hline Mean velocity $\left(\mathrm{m} \cdot \mathrm{s}^{-1}\right)$ & 0.85 & 0.69 \\
\hline Mean with (m) & 17.5 & 21.2 \\
\hline Mean depth (m) & 0.76 & 0.6 \\
\hline Mean temperature $\left({ }^{\circ} \mathrm{C}\right)$ & 10.15 & 10.18 \\
\hline Mean conductivity $\left(\mu \mathrm{S} \cdot \mathrm{cm}^{-1}\right)$ & 87 & 38.5 \\
\hline Mean pH & 8.1 & 8.2 \\
\hline Mean dissolved $\mathrm{O}_{2}\left(\mathrm{mg} \mathrm{L}^{-1}\right)$ & 7.2 & 7.8 \\
\hline Mean $\%$ of boulders & 62 & 68 \\
\hline
\end{tabular}

* UTM = Universal Transverse Mercator Geographic Coordinate System.

spawning site of Chinook salmon in Chile (Soto et al., 2007). In Laguna Los Patos, non-native rainbow trout (O. mykiss Walbaum) and brown trout (Salmo trutta L.) are the most common fishes and Chinook salmon parr can be found seasonally from spring to early summer (September-January; Soto et al., 2007). Native fishes, including puye chico (Galaxias maculatus Jenyns) and puye grande (G. platei Steindachner) are also present but in much lower densities. At the Rio Pescado reference site, the fish assemblage is similar to Laguna Los Patos except that Chinook salmon has never been reported there (Soto et al., 2007; Correa and Gross, 2008).

We visited both sites during April and May (2007-2008) to cover the end of the Chinook salmon breeding season (Soto et al., 2007). In Laguna Los Patos, we sampled 50-200 m downstream of the Chinook salmon historical spawning area and in the reference site we randomly selected a comparable reach with similar hydrological and riparian vegetation characteristics (Table I). We examined the potential use of MDN from salmon carcasses in freshwater food webs using stable isotopes of $\mathrm{C}$ and $\mathrm{N}$ in periphyton, macroinvertebrates (scrapers), and fishes. We sampled periphyton by scraping the dominant cobble substrate. We collected macroinvertebrates (i.e. aquatic insects and freshwater snail Chilina sp.) by using a $25 \mathrm{~cm}$ diameter stovepipe benthic sample corer. We sampled fishes by using standard electrofishing procedures obtaining a dorsal portion of muscle from rainbow trout and brown trout (15 to $25 \mathrm{~cm}$ total length), Chinook salmon carcasses (90 to $120 \mathrm{~cm}$ total length), and Chinook salmon parr (5 to $10 \mathrm{~cm}$ total length). We stored tissues at $0{ }^{\circ} \mathrm{C}$ for transportation. In the laboratory they were dried at $60{ }^{\circ} \mathrm{C}$ for $48 \mathrm{~h}$ and ground into a fine powder. We analyzed all samples at the Stable Isotope Research Unit, Crop and Soil Sciences Department, Oregon State University. Isotope ratios were expressed in parts per thousand (\%) according to the equation:

$$
X=\left[\left(R_{\text {sample }}-R_{\text {standard }}\right) / R_{\text {standard }}\right] \times 10^{3}
$$




\section{Table II}

Stable isotopes of $N$ and $C$ from different studies in southern South America conducted in streams invaded by Chinook salmon and in reference systems. $S D=$ standard deviation; Ref = Reference; Chi = Chinook salmon invaded. For the nutrient origin $T=$ terrestrial, $F=$ freshwater, and $M=$ marine.

\begin{tabular}{|c|c|c|c|c|c|c|c|c|c|c|}
\hline Item & Category & Ref/Chi & Origin & $\begin{array}{c}\text { Range/mean } \\
\delta^{15} \mathrm{~N}\end{array}$ & SD & $\begin{array}{c}\text { Range/ } \\
\text { mean } \delta^{13} \mathrm{C}\end{array}$ & SD & $n$ & Study area & Citation \\
\hline \multirow{2}{*}{ Soil } & $\begin{array}{c}\text { Andes } \\
\text { mountains }\end{array}$ & Ref & $\mathrm{T}$ & -2.90 & & -28.30 & & & Southern Chile & (4) \\
\hline & $\begin{array}{c}\text { Old-growth } \\
\text { forest }\end{array}$ & Ref & $\mathrm{T}$ & -4.00 & & & & & Southern Chile & (2) \\
\hline \multirow{2}{*}{$\begin{array}{l}\text { Primary } \\
\text { production }\end{array}$} & \multirow[t]{2}{*}{ Periphyton } & Ref & $F$ & -0.14 & 1.40 & -33.37 & 0.26 & 4 & Pescado River, Chile & $\begin{array}{c}\text { Present } \\
\text { study }\end{array}$ \\
\hline & & Chi & $\mathrm{F}$ & 5.00 & 0.46 & -33.40 & 0.26 & 3 & $\begin{array}{c}\text { Laguna Los Patos, } \\
\text { Chile }\end{array}$ & \begin{tabular}{|c|} 
Present \\
study
\end{tabular} \\
\hline \multirow{4}{*}{$\begin{array}{l}\text { Secondary } \\
\text { production }\end{array}$} & \multirow[t]{2}{*}{$\begin{array}{l}\text { Aquatic } \\
\text { insects }\end{array}$} & Ref & $F$ & 1.80 & 0.63 & -33.92 & 0.91 & 2 & Pescado River, Chile & $\begin{array}{c}\text { Present } \\
\text { study }\end{array}$ \\
\hline & & Chi & $\mathrm{F}$ & 5.01 & 0.22 & -31.11 & 0.36 & 3 & $\begin{array}{c}\text { Laguna Los Patos, } \\
\text { Chile }\end{array}$ & $\begin{array}{c}\text { Present } \\
\text { study }\end{array}$ \\
\hline & \multirow[t]{2}{*}{$\begin{array}{c}\text { Freshwater } \\
\text { snail }\end{array}$} & Ref & $F$ & 1.85 & 0.66 & -32.37 & 0.52 & 2 & Pescado River, Chile & $\begin{array}{c}\text { Present } \\
\text { study }\end{array}$ \\
\hline & & Chi & $\mathrm{F}$ & 3.86 & 0.08 & -27.91 & 3.31 & 5 & \begin{tabular}{|c|} 
Laguna Los Patos, \\
Chile
\end{tabular} & \begin{tabular}{|c|} 
Present \\
study
\end{tabular} \\
\hline \multirow{3}{*}{$\begin{array}{l}\text { Brown } \\
\text { trout }\end{array}$} & \multirow[t]{3}{*}{ Free-living } & Ref & $F$ & 7.12 & 1.47 & -31.82 & 1.20 & 10 & Pescado River, Chile & $\begin{array}{c}\text { Present } \\
\text { study }\end{array}$ \\
\hline & & Chi & $\mathrm{F}$ & 6.40 & 0.89 & -28.34 & 0.31 & 8 & $\begin{array}{c}\text { Laguna Los Patos, } \\
\text { Chile }\end{array}$ & \begin{tabular}{|c|} 
Present \\
study
\end{tabular} \\
\hline & & Ref & $\mathrm{F}$ & 5.00 to 11.60 & & & & & Southern Chile & (1) \\
\hline \multirow{6}{*}{$\begin{array}{l}\text { Rainbow } \\
\text { trout }\end{array}$} & \multirow[t]{4}{*}{ Free-living } & Ref & $\mathrm{F}$ & 7.50 & 1.61 & -31.33 & 1.17 & 8 & Pescado River, Chile & $\begin{array}{c}\text { Present } \\
\text { study }\end{array}$ \\
\hline & & Chi & $F$ & 6.54 & 1.85 & -29.29 & 3.30 & 8 & $\begin{array}{c}\text { Laguna Los Patos, } \\
\text { Chile }\end{array}$ & \begin{tabular}{|c|} 
Present \\
study
\end{tabular} \\
\hline & & Ref & $\mathrm{F}$ & 5.50 to 8.80 & & & & & Southern Chile & (1) \\
\hline & & Ref & $\mathrm{F}$ & 10.54 & & -32.65 & & & Southern Chile & (7) \\
\hline & Farmed & Ref & $\mathrm{F} / \mathrm{M}$ & 15.10 & & -27.74 & & & Southern Chile & (7) \\
\hline & Anadromous & Chi & $\mathrm{F}$ & 14.41 to 16.08 & & $\begin{array}{c}-20.21 \text { to } \\
-18.12\end{array}$ & & & $\begin{array}{l}\text { Santa Cruz River, } \\
\text { Argentina }\end{array}$ & (3) \\
\hline \multirow{5}{*}{$\begin{array}{l}\text { Chinook } \\
\text { salmon }\end{array}$} & $\begin{array}{c}\text { Introduced/ } \\
\text { fry }\end{array}$ & Chi & $\mathrm{F}$ & 5.83 & 0.09 & -16.02 & 1.21 & 10 & $\begin{array}{c}\text { Laguna Los Patos, } \\
\text { Chile }\end{array}$ & \begin{tabular}{|c|} 
Present \\
study
\end{tabular} \\
\hline & \multirow[t]{4}{*}{$\begin{array}{c}\text { Adult-carca } \\
\text { sses }\end{array}$} & Chi & M & 17.81 & 1.12 & -26.47 & 0.50 & 5 & $\begin{array}{c}\text { Laguna Los Patos, } \\
\text { Chile }\end{array}$ & $\begin{array}{c}\text { Present } \\
\text { study }\end{array}$ \\
\hline & & Chi & $\mathrm{M}$ & 17.07 to 18.85 & & $\begin{array}{l}-19.30 \text { to } \\
-17.44\end{array}$ & & & Caterina, Argentina & (3) \\
\hline & & Chi & $M$ & 16.8 to 18.15 & & $\begin{array}{c}-19.19 \text { to } \\
-17.23\end{array}$ & & & $\begin{array}{c}\text { Grande Bay, } \\
\text { Argentina }\end{array}$ & (3) \\
\hline & & Chi & $M$ & 16.20 to 17.80 & & $\begin{array}{c}-18.00 \text { to } \\
-15.50\end{array}$ & & & $\begin{array}{c}\text { Ovando-Capataia, } \\
\text { Argentina }\end{array}$ & (5) \\
\hline \multirow{3}{*}{$\begin{array}{l}\text { Marine } \\
\text { fishes }\end{array}$} & Anchovy & Ref & M & 17.83 & & -15.56 & & & Chile & (6) \\
\hline & Hake & Ref & $M$ & 17.67 & & -14.42 & & & Chile & (6) \\
\hline & Herring & Ref & $M$ & 17.67 & & -14.61 & & & Chile & (6) \\
\hline $\begin{array}{l}\text { Marine } \\
\text { mammals }\end{array}$ & Sea Lion & Ref & $M$ & 20.97 & & -12.48 & & & Chile & (6) \\
\hline
\end{tabular}

(1) Arismendi et al., 2011; (2) Boeckx et al., 2005; (3) Ciancio et al., 2005; (4) Etcheverría et al., 2009; (5) Fernández et al., 2010; (6) Hückstädt et al., 2007; (7) Schröder et al., 2010. 
where $X$ is $\delta^{13} \mathrm{C}$ or $\delta^{15} \mathrm{~N}$ and $R$ is the corresponding ${ }^{13} \mathrm{C}:{ }^{12} \mathrm{C}$ or ${ }^{15} \mathrm{~N}:{ }^{14} \mathrm{~N}$ ratio. The standards used were Vienna Peedee belemnite for $\mathrm{C}$ and $\mathrm{N}_{2}$ for $\mathrm{N}$. Positive delta values indicated enrichment of the heavier isotope and negative values indicated depletion.

Because of the difficultly in locating additional streams with a long-term history of confirmed Chinook salmon spawning within $500 \mathrm{~km}$ of Laguna Los Patos (see Correa and Gross, 2008) we contrasted our results with other studies in streams of Patagonia with and without the presence of Chinook salmon (Table II).

At the reference site, periphyton was highly depleted in $\delta^{15} \mathrm{~N}$ compared to Laguna Los Patos and had a comparable level to the terrestrial soils (Figure 1, Table II). Also, at the reference site, aquatic insects (scrapers) and freshwater snails were more depleted in $\delta^{15} \mathrm{~N}$ compared to fishes. Conversely, there were a similar enrichment in $\delta^{15} \mathrm{~N}$ on periphyton, aquatic insects, freshwater snails and fishes at Laguna Los Patos. Moreover, Chinook salmon was highly enriched of $\delta^{13} \mathrm{C}$ followed by Chinook parr at Laguna Los Patos but, periphyton showed a similar and depleted level of $\delta^{13} \mathrm{C}$ at both sites. Aquatic insects, freshwater snail, and fishes were more enriched of $\delta^{13} \mathrm{C}$ at Laguna Los Patos than at the reference site. Rainbow trout and freshwater snails had the greatest variability in $\delta^{13} \mathrm{C}$, a different pattern than seen at the reference site.

Our results suggest that MDN from salmon carcasses are most likely being incorporated into stream food webs of an invaded river where Chinook salmon is well established. Specifically, at Laguna Los Patos, periphyton and aquatic insects show the greatest enrichment of $\delta^{15} \mathrm{~N}$ (5-6\%), similar to enrichment levels reported in Alaska (Chaloner et al., 2002). Our results are also in agreement with the idea that periphyton and aquatic insects are two lower trophic levels that better incorporate the MDN from salmon carcasses as seen in North America (Wold et al., 1999; Chaloner et al., 2002; Claeson et al., 2006; Kohler et al., 2008).

The role of salmon carcass inputs in South American streams is ecologically interesting because it illuminates the function of nutrient subsidies from an invasive species perspective. This may be important in resource-limited systems such as southern Chilean streams (Campos, 1985) where MDN subsides from Chinook salmon carcasses could also facilitate other invasions (i.e., rainbow and brown trout; see Kiernan et al., 2010). In North American streams MDN from salmon carcasses have been linked to increases in growth rates, survival and reproduction of native salmonids (Chaloner et al., 2002; Wipfli et al., 2003; Kiernan et al., 2010), but the expected impacts may vary depending on local availability of nutrients or other food web processes (Stockner, 2003). The higher variability of $\delta^{13} \mathrm{C}$ observed in rainbow trout and freshwater snails could be result of direct consumption of salmon material (i.e. we observed in situ salmon eggs in trout stomachs and freshwater snails grazing over salmon carcasses).

In their native ecosystems salmon carcasses affect both heterotrophic and autotrophic processes (Holtgrieve and Schindler, 2011) with ecological consequences that persist over time (Verspoor et al., 2011). However, in invaded systems we still understand little about how these newly available nutrient subsidies may change ecosystem functioning. Since Chinook salmon are currently undergoing rapid expansion in South America (Correa and Gross, 2008) further efforts are needed to elucidate the consequences of MDN at a broader scale. This is a preliminary study that provides a first attempt to identify where MDN from Chinook salmon carcasses are being incorporated in food webs of invaded streams but it lacks replication. We encourage future studies to include more sites covering a broader extent range of stream types invaded and not invaded by Chinook salmon. Further, studies that consider riparian zones in streams where Chinook salmon have been introduced, including plants (i.e. N-fixing species) and terrestrial organisms, will illuminate our understanding about if MDN are also being transported and incorporated in those terrestrial ecosystems.

\section{ACKNOWLEDGEMENTS}

Jose Luis Iriarte, Carlos Leal, and the Limnology and Oceanography class at Universidad Austral de Chile Campus Puerto Montt for helping with samplings. Brooke Penaluna, Allison 
Evans, Jason Dunham, and two anonymous reviewers provided insights and discussion. I. Arismendi was supported by Comisión Nacional de Ciencia y Tecnología of Chile (CONICYT) and Millennium Nucleus Forest Ecosystem Services (FORECOS) P04-065-F of Ministerio de Planificación of Chile.

\section{REFERENCES}

Arismendi I., González J., Soto D. and Penaluna B., 2011. Piscivory and diet overlap between two nonnative fishes in southern Chile. Austral Ecol., doi: 10.1111/j.1442-9993.2011.02282.x.

Becker L.A., Pascual M.A. and Basso N.G., 2007. Colonization of the Southern Patagonia Ocean by exotic Chinook Salmon. Conserv. Biol., 21, 1347-1352.

Boeckx P., Paulino L., Oyarzún C., Van Cleemput O. and Godoy R., 2005. Soil $\delta^{15} \mathrm{~N}$ patterns in oldgrowth forests of southern Chile as integrator for N-cycling. Isotopes Environ. Health Stud., 413, 249-259.

Campos H., 1985. Distribution of fishes in the Andean rivers in the South of Chile. Arch. Hydrobiol., 104, 169-191.

Chaloner D.T., Martin K.M., Wipfli M.S., Ostrom P.H. and Lamberti G.A., 2002. Marine carbon and nitrogen in southeastern Alaska stream food webs: evidence from artificial and natural streams. Can. J. Fish. Aquat. Sci., 59, 1257-1265.

Ciancio J.E., Pascual M.A., Lancelotti J., Rossi C. and Botto F., 2005. Natural colonization and establishment of a Chinook salmon Oncorhynchus tshawytscha, population in the Santa Cruz River, an Atlantic basin of Patagonia. Environ. Biol. Fish., 74, 219-227.

Claeson S.M., Li J.L., Compton J.E. and Bisson P.A., 2006. Response of nutrients, biofilm, and benthic insects to salmon carcass addition. Can. J. Fish. Aquat. Sci., 63, 1230-1241.

Correa C. and Gross M.R. 2008. Chinook salmon invade southern South America. Biol. Invasions, 10, 615-639.

Di Prinzio C.Y. and Pascual M.A., 2008. The establishment of exotic Chinook salmon (Oncorhynchus tshawytscha) in Pacific rivers of Chubut, Patagonia, Argentina. Ann. Limnol., 1, 61-68.

Etcheverría P., Huygens D., Godoy R., Borie F. and Boeckx P., 2009. Arbuscular mycorrhizal fungi contribute to ${ }^{13} \mathrm{C}$ and ${ }^{15} \mathrm{~N}$ enrichment of soil organic matter in forest soils. Soil Biol. Biochem., 41 , 858-861.

Fernández D.A., Ciancio J., Ceballo S.G., Riva-Rossi C. and Pascual M.A., 2010. Chinook salmon (Oncorhynchus tshawytscha, Walbaum, 1792) in the Beagle Channel, Tierra del Fuego: the onset of an invasion. Biol. Invasions, 12, 2991-2997.

Holtgrieve G.W. and Schindler D.E., 2011. Marine-derived nutrients, bioturbation, and ecosystem metabolism: reconsidering the role of salmon in streams. Ecology, 92, 373-385.

Hückstädt L.A., Rojas C.P. and Antezana T., 2007. Stable isotope analysis reveals pelagic foraging by the Southern sea lion in central Chile. J. Exp. Mar. Biol. Ecol., 347, 123-133.

Kiernan J.D., Harvey B.N. and Johnson M.L., 2010. Direct versus indirect pathways of salmon-derived nutrient incorporation in experimental lotic food webs. Can. J. Fish. Aquatic Sci., 67, 1909-1924.

Kohler A.E., Rugenski A. and Taki D., 2008. Stream food web response to a salmon carcass analogue addition in two central Idaho, USA streams. Freshw. Biol., 53, 446-460.

McDowall R.M., 1994. The origins of New Zealand's Chinook salmon, Oncorhynchus tshawytscha. Marine Fisheries Review, 56, 1-7.

Schröder V. and Garcia de Leaniz C., 2010. Discrimination between farmed and free-living invasive salmonids in Chilean Patagonia using stable isotope analysis. Biol. Invasions, doi: 10.1007/s10530-010-9802-z.

Soto D., Arismendi I., Di Prinzio C. and Jara F., 2007. Establishment of Chinook salmon (Oncorhynchus tshawytscha) in Pacific basins of southern South America and its potential ecosystem implications. Rev. Chil. Hist. Nat., 80, 81-98.

Stockner J.G., 2003. Nutrients in Salmonid Ecosystems: Sustaining Production and Biodiversity. American Fisheries Society, Bethesda.

Verspoor J.J., Braun D.C., Stubbs M.M. and Reynolds J.D., 2011. Persistent ecological effects of a salmon-derived nutrient pulse on stream invertebrate communities. Ecosphere, doi: 10.1890/ES10-00011.1.

Wipfli M.S., Hudson J.P., Caouette J.P. and Chaloner D.T., 2003. Marine subsidies in freshwater ecosystems: Salmon carcasses increase the growth rates of stream-resident salmonids. Trans. Am. Fish. Soc., 132, 371-381.

Wold A.K.F. and Hershey A.E., 1999. Effects of salmon carcass decomposition on biofilm growth and wood decomposition. Can. J. Fish.Aquat. Sci., 56, 767-773. 